\title{
Analysis of Brown Crepe Industry Performance in Banjar Regency South Kalimantan Province Indonesia
}

\author{
Yanti, N.D. ${ }^{1}$, E. Radiah $^{2}$, Andu. Hanafie ${ }^{3}$ \\ 1,2,3 Faculty of Agriculture, Lambung Mangkurat University, Banjarbaru, Indonesia
}

Corresponding Author: Nuri Dewi Yanti

Faculty of Agriculture Lambung Mangkurat University, Jln. A.Yani KM 36 Simpang Empat, Banjarbaru, Indonesia 79714

\begin{abstract}
This study aims to calculate the value added of unused rubber into brown crepe (BC) as an effort to increase farmers' income. The results of this study were expected to formulate strategies for $\mathrm{BC}$ business. Cigar Box approach was used to understand cost structure and revenue of $\mathrm{BC}$ and predict financial performance of the business. The results showed that variable cost was Rp 5,578.00/kg, and fixed cost was Rp 392.00/unit of product. Value added produced was Rp 2,005.00/kg (32.34\%). Furthermore, the profit incurred was Rp 230.00/kg (3.84\% of selling price), while the gross margin is Rp 622.00/kg (10.03\%). This level was considered very risky because it is far from the normal level $(\geq 25 \%)$. On the other hand, this business should be encouraged since it provides additional income for farmers by selling the unused rubber products. Increasing gross margin can be done by reducing variable costs and/or increasing revenue. Variable costs can be lowered by decreasing the cost of procuring raw materials. The second option was to return investor's fund. Another alternative was to increase selling price. This option was more likely since there was few BC manufacturers in the area. Several scenarios were prepared for business planning. The scenario that gave a minimum gross margin of $25 \%$ when raw material price decreased by $10 \%$, and $\mathrm{BC}$ selling price was increased by $10 \%$. However, when investor's fee removed, the reduction in the price of raw materials was only $8 \%$, and so the BC selling price only needed to increase by $8 \%$.
\end{abstract}

Keywords: brown crepe rubber, gross margin, cigar-box analysis; community welfare.

\section{INTRODUCTION}

Plantation commodities are a green gold mine for national income and foreign exchange for non-oil and gas industry. Indonesia's export value for the plantation in 2014 reached USD 28.234 billion. Rubber commodities were second only to palm oil (CPO and other palm oil) with a value of more than USD 2.94 billion. The prospect of world shipping is expected to remain bright with the increasing number of industrial companies using rubber raw materials more and more with increasing population. In addition, with the increasingly strong awareness of the environment in which some of the world's leading tire factories have begun to introduce green tire types that have more natural rubber content. On the other hand, with the decreasing sources of petroleum and unrenewable resources as synthetic rubber raw materials, competition with these substitution products has diminished.

Most rubber plants in Indonesia are found in Sumatra and Kalimantan where smallholder plantations dominate the plantation area. One of the centers of rubber production in South Kalimantan is in the Banjar Regency. The cultivation of rubber plantations has been carried out by the community for generations, so that the life of the people in Banjar Regency is very dependent on this plant in sustaining the household economy. In general, rubber 1801 products produced from smallholder plantations are in the form of lumps or slabs. These products are usually sold to crumb rubber factories as raw material for making Standard Indonesian Rubber (SIR) 20. Meanwhile, in South Kalimantan alone there are many crumb rubber factories, so the price level is usually in the hands of buyers. Therefore, the oligopolistic market structure leads to monopolistic practices (only one buyer) that has the power to reduce prices at the farm level as lump products are still raw material that cannot be exported. Thus, diversification of rubber products (bokar) is further emphasized through increasing added value so that prices at the farmer level will be better and more stable, which in turn will increase the income and welfare of rubber farmers in particular and society in general. Another important aspect is that farmers do not need to depend on crumb rubber factories.

Most of the quality natural rubber products are used as raw material for the tire industry which is exported to tire producing countries such as America, Japan, China, and other countries. On the other hand, BC which is a lower quality rubber product since it is made from unused rubber (ground lump or rejected lump as its raw materials). Therefore, BC processing business is very important because it may increase farmers' income by utilizing unused rubber products. Generally, BC is used as a mixture in 


\section{"Analysis of Brown Crepe Industry Performance in Banjar Regency South Kalimantan Province Indonesia"}

making crumb rubber to meet the needs of domestic raw materials for retreading industries, household appliances, or for the footwear, and other rubber industries.

The forerunner of the BC factory in Banjar Regency is a form of central government assistance through the Local and Regional Economic Development program (PELD). Banjar Regency is one of eight regencies/cities that get priority for the development of the local economy which is expected to be a patron for other regions. Therefore, it is necessary to study the existing BC industry and future development strategies so that the impact can be enjoyed by the wider community.

In general, this study aimed to study the BC downstream industry and its development prospects in the future in order to improve the welfare of rubber and other business people. Specifically, this goal was translated into three, namely: 1) Calculating the value of added bokar lump into a $\mathrm{BC}$ product, 2) Reviewing the cost and revenue structure of $\mathrm{BC}$ processing business, with Cigar Box formulas, and 3) Analyzing the profitability of the $\mathrm{BC}$ processing industry.

\section{LITERATURE REVIEW}

At this time Indonesia ranks first for the area of the world's natural rubber area beyond Thailand and Malaysia. However, Indonesia's rubber productivity is still far from the two countries. In addition, the quality of rubber produced is also relatively low which causes low rubber values. Basically, the value of rubber products can be increased through the creation of added value, which is further processing into processed products such as ribbed smoked sheets, dried sheets, compound rubber, BC, and other rubber products.

The downstream industry of $\mathrm{BC}$ is one of the efforts to increase the value added of rubber-based ingredients produced by rubber plants. The existing industry is an industry that is under the business of a rubber farmer group known as the SukaMakmur Rubber Processing and Marketing Unit (UPPB). As a small industry in rural areas, the business management of UPPB SukaMakmur is still relatively simple so it requires a reliable business strategy management that can be formulated into a business model.

In running a business, the main goal of a producer (including farmers) is to make a profit, although there are several other objectives such as job creation or providing certain goods or services. To get a business that provides profits, the producers are faced with various considerations to make decisions that affect the state of their business.

One consideration in making decisions in business is to use economic principles, namely by considering the quality and price of the product, the cost of production and the number of products sold so that profits can be calculated. This financial calculation allows them to make the right decision to determine the next step (Lieshout, 2015). Furthermore, with the profits obtained, a business can maintain its business continuity and furthermore to be able to develop the business further. The amount of profit a business depends on several factors (Mulyadi, 2001), such as costs, selling prices, and sales and production volumes. The amount of sales volume affects the volume of production and then the production volume will affect the size of production costs. Thus, profits can be increased by getting additional income or by reducing costs.

Cigar Box is an instrument to help an entrepreneur in calculating costs, margins, contributions, break-even volume and profitability of the business being run. The use of Cigar Boxes is only based on a simple Excel program, so it is easily applied by a beginner, even like a small businessman or farmer in the countryside. This method developed by Olivier van Lieshout and Orlando van Geuns. It has been used by companies engaged in agriculture throughout the world such as projects sponsored by the European Bank for Reconstruction and Development (EBRD) in Morocco, Egypt, Ukraine, Montenegro and Bosnia (https://en.wikipedia.org/wiki/Cigar_Box_method).

Many business models have been developed by experts. According to Fielt (2013) the business model is a logical thinking about the model adopted by an organization or company, namely how to create, provide and capture customer values that will be realized to meet consumer desires, what benefits consumers receive in the form of economy, social or other aspects.

\section{RESEARCH AND METHODS}

\section{Types and Data Sources}

The type of data needed in this study was cross section data, which was showing a point at a certain time. The data source came from primary data which is from business actors involved in brown crepe processing industry. The intended business actors include rubber farmers as suppliers of lump (ground lump, rejected lump, and tatal) as the raw materials of BC, and manufacturer of BC. Primary data was obtained by distributing questionnaires for farmers. Whereas for $\mathrm{BC}$ processing entrepreneurs conducted in-depth interviews. Secondary data were obtained from related agencies such as South Kalimantan Provincial Plantation Office, Plantation and Livestock Office of Banjar Regency, Industry and Trade Office of Banjar Regency, the Central Statistics Agency, and other relevant agencies.

\section{Sampling Method}

In-depth interview conducted for business people who were members of the SukaMakmur UPBB which was a group of rubber farmers who produce BC. Respondent farmers who supply the raw materials were sampled in this study were farmers around the BC product processing site. Respondents were selected by simple random sampling method where each farmer in the population had the same opportunity to be chosen as the respondent. There are two villages which are Sungai Bokor Village, Mataraman District and Batu Balian Village, Simpang Empat District. 


\section{"Analysis of Brown Crepe Industry Performance in Banjar Regency South Kalimantan Province Indonesia"}

\section{Data Analysis}

The research focused on collecting primary and secondary data to answer goals one to three that emphasize the upstream sub-system, namely the availability of primary raw materials and industrial supporting materials and the onfarm sub-system, namely the performance of the BC processing industry itself. Data is analyzed using Cigar-Box Method (Liesthout, 2015a) which included the calculation of product added value, cost structure, determination of the amount and selling price of the product as a basis for analyzing company profits and developing a business scale.

\section{RESULTS AND DISCUSSION}

\section{Cost Structure Analysis}

A cost structure analysis is a good way to have in-depth look at how a business cost affects its optimal quantity of goods to produce such as BC. In general, cost is classified into two different types i.e. variable costs and fixed costs.

\section{Variable Cost.}

Variable costs are costs that vary according to the level of production volume. If the entrepreneur wants a lot of production, the higher the variable costs incurred. Variable costs required in processing $\mathrm{BC}$ products are in the form of raw material usage costs and auxiliary costs, as well as labor costs. Using the Cigar Box analysis variable costs was divided into four which are:

\section{Cost of Raw Materials and Auxiliary Materials (VC 1)}

There are three kinds of raw materials needed in the BC processing process, namely ground lumps, rejected lumps, and rubber chips (tatal). These three ingredients are the main raw materials for manufacturing BC products. All three are lumps with the lowest quality, so the processed products into $\mathrm{BC}$ are an alternative use of materials that can hardly be used anymore. Of the three raw materials, rejected lump was the best material due to its least shrinkage, which was about $15 \%$ but dry rubber content (K3) was relatively small. While rubber chips or tatal loss was $38-40 \%$. Raw materials that were processed in the range of 40-50 ton/month consist of $75-80 \%$ are from ground lump, while the rest (20-25\%) are from rejected and tatal.

Processing at the time of the study showed that 43 tons of raw materials were processed, consisting of 32 ton of ground lumps, 8 ton of rejected lumps, and 3 ton of tatal, with an average price of each raw material of $\mathrm{Rp} 3,000 ; \mathrm{Rp}$ 4,000; and Rp 1,200/kg. Thus, the overall cost incurred for the procurement of raw materials was Rp 131,600,000/ period.

On the other hand, the auxiliary material for processing $\mathrm{BC}$ was water. As stated in the front, basically $\mathrm{BC}$ processing was only the cleaning of raw materials which are then glued together. Then, it was formed in sheets that are ready use as a mixture for other rubber processed materials. Water costs are calculated based on the amount of water used during the process, which was approximately as much as $10 \mathrm{~L}$ for every one $\mathrm{kg}$ of product. Assuming the 1803 cost of water was Rp 30/L, the required cost was Rp 300/kg, so the total cost of water was $\mathrm{Rp} 8,884,500$ for each production process.

$\mathrm{BC}$ processing was carried out with the help of a grinding machine (mangal) which requires a generator as its driver. For this purpose, diesel fuel was needed. It needed as much as $30 \mathrm{~L} /$ day. In this study, the data used was 28 days (one month), with the price of diesel fuel of Rp 6,500/L (subsidized), the total cost of diesel fuel was $\mathrm{Rp}$ $5,460,000 /$ period. In other words, the cost to produce one $\mathrm{kg}$ of BC was Rp 184,37.

\section{Labor Cost (VC 2)}

Labor costs were costs paid to workers who work in processing BC. The scope of work carried out was to remove raw materials from plastic sacks and clean from plastic ropes and other materials, grind while gluing together, roll, and weigh. Then put in a pool (temporary storage) if the shipment was not carried out on the same day. Upon delivery, the workforce would stack the $\mathrm{BC}$ inside a truck or pick-up. The workforce employed in the BC processing industry was 3-4 people. Working hours started from 9:00 a.m. to 5:00 p.m., with an hour break, and can be continued at night if the supply of raw materials was quite large, i.e. from 21.00-24.00. The wages of workers were paid in the amount of Rp $450 / \mathrm{kg}$. The work done consist of cleansing; washing, grinding, and glue; rolling and weighing, and transport to the pond before sending to the buyer. The overall labor cost was Rp 13,326,750/period.

\section{Other Cost (VC3)}

Usually capital is grouped into fixed costs which does not depend on the amount of output produced. However, in this case, the capital invested into the company was classified as variable cost which the producer will pay a fee based on the amount of output produced which was Rp 200/kg. agreement, capital investment costs were categorized as variable costs. With a total production of $29,615 \mathrm{~kg}$, this cost was Rp 5,923,000.

\section{Packaging Fee (Packing, VC 4)}

Basically, there was no specific BC product packaging. After the product was milled while being cleaned with running water, then glued to each other into sheets. The BC product sheet was rolled up and moved to a separate place that has been provided, usually put in a storage pond first, then transferred directly into the truck or pick-up. Alternatively, it was arranged into a dry place (warehouse) before being sent. Therefore, the cost of packaging was included to the costs paid to workers who carry out this process.

\section{Distribution Costs (VC 5)}

BC products are marketed at Kapuas Regency, Central Kalimantan Province. Delivery of goods was generally carried out every week using a truck, with the number of products sent on average 8.0 ton/week. If the amount of production was relatively small as in the dry months, then 


\section{"Analysis of Brown Crepe Industry Performance in Banjar Regency South Kalimantan Province Indonesia"}

shipping was only using a pick-up car with only 2.5 ton of product capacity. This distribution fee includes the cost of a pick-up amounting to Rp 300,000/trip). Meanwhile, if more $\mathrm{BC}$ products were produced, it would be more efficient, and transportation was carried out by truck, which was Rp 800,000 one way with a loading capacity of approximately eight ton. In addition, other costs are the loading and unloading costs of Rp $100 / \mathrm{kg}$, which was to lift from the storage pond into the truck for $\mathrm{Rp} 50 / \mathrm{kg}$ and lower the goods from the truck and put them in a place that has been prepared by the consumer Rp 50/kg. Generally, shipping was done once a week or four times per month. Thus, the overall distribution (shipping) costs were Rp 6,161,500.

Of all the cost components above, it can be seen that the total variable costs must be spent on the $\mathrm{BC}$ product processing business that was Rp 165,194,250 consisting of purchasing raw materials and auxiliary materials (VC1), labor wages (VC2), other costs (VC3) and costs distribution (VC5). Details of the variable processing costs of $\mathrm{BC}$ products per period can be seen in the table of $\mathrm{BC}$ product processing variable costs.

Table 1. Variable costs for processing brown crepe (BC)

\begin{tabular}{llll}
\hline No & Variable Cost & Cost $(\mathbf{R p )}$ & Percentage $(\boldsymbol{\%})$ \\
\hline 1 & Raw material & $131,600,000$ & 79.66 \\
2 & Water & $8,884,500$ & 5.38 \\
3 & Fuel & $5,460,000$ & 3.31 \\
4 & Labor & $13,326,750$ & 8.07 \\
5 & Other costs & $5,923,000$ & 3.59 \\
\hline \multicolumn{7}{l}{ Total } & $165,194,250$ & 100.00 \\
\hline
\end{tabular}

Source: Primary data processing, 2018.

\section{Fixed Cost}

Fixed costs were costs that must exist and remain issued without being bound by the presence or absence of the results obtained. There are depreciation of assets such as factory and warehouse, and other facilities; machinery (tools and equipment); interest; and overhead costs.

To determine the amount of depreciation costs in this study the straight-line method was applied, i.e. the initial value of the goods minus the residual value divided by economic age. Business premises used for processing BC products were relatively simple, where the walls are made of metal roof sheet on the bottom and wood on the top, while the roof was also of metal roof. Likewise with warehouses, where the situation was more open, which previously served as a place for BC products. The size of the place of business was $5 \times 19 \mathrm{~m}$, while the warehouse had a size of $10 \times 25 \mathrm{~m}$. The cost of these two places was calculated by depreciation costs.

The same thing applies to water storage ponds, waste ponds, and control holes. Water reservoirs were needed to store water, especially during the dry season so that water was always available during the processing. Water from the well was pumped and store in this pond, so that if the well water was insufficient during the production process, the water needs can be met from this pond. With a pool size of $5 \times 5 \times 1 \mathrm{~m}^{3}$, it could accommodate 20 ton of water. In addition, the pond also functioned to soak BC products before being sent to consumers. It was intended that the $\mathrm{BC}$ product does not change color to black, also reduces heavy shrinkage. In case of the residual value for machinery and equipment varies depending on the state of the machine and equipment at the end of the economic age. Generally, the remaining value calculated was only in the

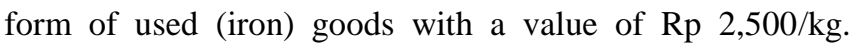
While other items were assumed to have no residual value. The depreciation costs of equipment calculated include the depreciation of grinding machines, scales, hoses, water pump, carts, shovels, generators, water reservoirs, and waste ponds. Table 2 shows the depreciation of company assets, whilst Table 3 shown monthly equipment depreciation costs incurred in $\mathrm{BC}$ product processing business.

Table 2. Depreciation of company assets in processing brown crepe (BC) products

\begin{tabular}{llllllll}
\hline No & Component & $\begin{array}{l}\text { Total } \\
(\text { unit })\end{array}$ & $\begin{array}{l}\text { Price } \\
\left(\text { Rp unit }^{-1}\right)\end{array}$ & $\begin{array}{l}\text { Cost } \\
(\mathbf{R p})\end{array}$ & $\begin{array}{l}\text { Economic } \\
\text { Age }\end{array}$ & $\begin{array}{l}\text { Residual } \\
\text { Value }_{(\text {Rp })}\end{array}$ & $\begin{array}{l}\text { Shrinkage }(\text { Rp } \\
\left.\text { month }^{-\mathbf{1}}\right)\end{array}$ \\
\hline 1 & Factory & 1 & $50,000,000$ & $50,000,000$ & 15 & 0 & 277,778 \\
2 & Warehouse & 1 & $200,000,000$ & $200,000,000$ & 15 & 0 & $1,111,111$ \\
3 & Water Pools & 1 & $25,000,000$ & $25,000,000$ & 12 & 0 & 173,611 \\
4 & Waste pond & 1 & $2,000,000$ & $2,000,000$ & 10 & 0 & 16,667 \\
5 & Control holes & 1 & 250,000 & 250,000 & 10 & 0 & 2,083 \\
\hline \multicolumn{2}{l}{ Total } & & & & & $1,581,250$ \\
\hline
\end{tabular}

Source: Primary data processing, 2018.

Table 3. Depreciation costs for machinery and business equipment for processing brown crepe (BC) products every month

\begin{tabular}{|c|c|c|c|c|c|c|c|}
\hline No & Component & $\begin{array}{l}\text { Amount } \\
\text { (unit) }\end{array}$ & $\begin{array}{l}\text { Price } \\
\left(\text { Rp unit }^{-1}\right)\end{array}$ & $\begin{array}{l}\text { Cost } \\
\text { (Rp) }\end{array}$ & $\begin{array}{l}\text { Economic } \\
\text { Age }\end{array}$ & $\begin{array}{l}\text { Residual } \\
\text { Value (Rp) }\end{array}$ & $\begin{array}{l}\text { Shrinkage (Rp } \\
\left.\text { month }^{-1}\right)\end{array}$ \\
\hline 1 & Grinding machine & 2 & $75,000,000$ & $150,000,000$ & 10 & $1,000,000$ & $1,241,667$ \\
\hline 2 & Generator & 1 & $50,000,000$ & $50,000,000$ & 12 & 750,000 & 342,014 \\
\hline 3 & Scales & 1 & $1,250,000$ & $1,250,000$ & 4 & 50,000 & 25,000 \\
\hline
\end{tabular}


"Analysis of Brown Crepe Industry Performance in Banjar Regency South Kalimantan Province Indonesia"

\begin{tabular}{llllllll}
4 & Carts (Arco) & 3 & 300,000 & 900,000 & 3 & 15,000 & 24,583 \\
5 & Shovel & 2 & 50,000 & 100,000 & 2 & 0 & 4,167 \\
6 & Hose & 0.5 & 400,000 & 200,000 & 0.5 & 0 & 33,333 \\
\hline Total & & & & & $1,670,764$ \\
\hline
\end{tabular}

Source: Primary data processing, 2018.

\section{Interest (FC3)}

The capital used was from Mr. Jamsar and from investors who invested their capital in this business. In addition, this processing business also obtained capital from the People's Business Credit channeled by Bank Rakyat Indonesia (BRI), with an interest rate of $9 \%$ p.a. The amount of credit disbursed amounted to Rp $200,000,000$ so the capital interest to be paid was $\mathrm{Rp}$ $1,500,000 /$ month. Meanwhile, the calculation of remuneration from investors was based on the amount of production produced. Therefore, this fee was not included in the fixed costs.

\section{Overhead Cost (FC4)}

Factory overhead cost was all costs incurred during the production process except raw material costs and direct labor costs. This cost was used to express some indirect costs associated with manufacturing products, namely the supporting costs incurred in making the product. In this analysis, overhead costs include employee's salary, and maintenance costs.

\section{a. Salary}

There were two people accounted who work as permanent employee in this BC processing unit. They were the manager and the mechanical personnel. The manager was the person who responsible for the whole business, especially in relation with external affairs. Meanwhile the mechanic was responsible for the internal enterprise such maintenance of equipment and machinery, also in administrative task. The manager's salary was calculated as $\mathrm{Rp} \mathrm{3,500,000/month,} \mathrm{while} \mathrm{the} \mathrm{salary} \mathrm{of} \mathrm{a}$ mechanical employee was Rp 2,500,000/month.

\section{b. Maintenance cost}

The maintenance costs referred as the costs for financing the replacement of engine and tool spare parts. Maintenance cost of

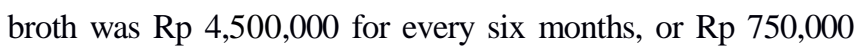
month. In addition, the replacement of the coupling (the link between the engine and the dynamo on the generator) was $\mathrm{Rp}$ 300,000 in two years or Rp 12,500/month.

\section{c. Communication costs}

Communication was needed in terms of procurement of raw materials and making agreements in the sale (marketing) of products. This communication fee was set at $\mathrm{Rp}$ 100,000/month. Details regarding all fixed costs incurred for BC product processing business could be seen in Table 4 .

Table 4. Total Fixed Costs of brown crepe (BC) product processing per month

\begin{tabular}{|c|c|c|c|}
\hline No & Cost Component & $\operatorname{Cost}\left(\operatorname{Rp}\right.$ month $\left.^{-1}\right)$ & Percentage $(\%)$ \\
\hline 1 & Depreciation of business premises, warehouses and ponds & $1,581,250$ & 13.61 \\
\hline 2 & Depreciation of machines and machines & $1,670,764$ & 14.39 \\
\hline 3 & Capital costs & $1,500,000$ & 12.91 \\
\hline \multirow[t]{4}{*}{4} & Factory overhead costs: & & \\
\hline & Salary & $6,000,000$ & 51.66 \\
\hline & Machine maintenance & 762,500 & 5.67 \\
\hline & Communication & 100,000 & 0.86 \\
\hline Total & & $11,614,514$ & 100.00 \\
\hline
\end{tabular}

Source: Primary data processing, 2018.

\section{Total Cost and Revenue}

Total costs are sum of total fixed costs and total variable costs. In the BC product processing business, total fixed cost was $\operatorname{Rp} 11,614,514$ whereas total variable cost was $\mathrm{Rp}$
$165,194,250$ so that total costs incurred by BC product was Rp 176,808,764/period (one month production process). The following table shows variable costs, fixed costs, and total processing costs of $\mathrm{BC}$ products.

Table 5. Variable costs, fixed costs, and total costs of processing brown crepe (BC) products

\begin{tabular}{llll}
\hline No & Cost Component & Big Cost $\left(\mathbf{R p ~ p e r i o d}{ }^{-1}\right)$ & Percentage $(\%)$ \\
\hline 1 & Variable costs & 165.194 .250 & 93,43 \\
\hline 2 & Fixed costs & 11.614 .514 & 6,57 \\
\hline & Total Cost & 176.808 .764 & 100,00 \\
\hline
\end{tabular}

Source: Primary data processing, 2018.

Companies generate revenues from sales of their products and services. BC production was sold to consumers outside
South Kalimantan, such as in Kapuas District, Central Kalimantan Province or in Pontianak (West Kalimantan). 


\section{"Analysis of Brown Crepe Industry Performance in Banjar Regency South Kalimantan Province Indonesia"}

Revenue received by the producer was the amount of BC production times its price. In this research, the number of BC products produced was $29,615 \mathrm{~kg}$, and the price was $\mathrm{Rp}$ $6,200 / \mathrm{kg}$, so that the revenue obtained from the processing of BC products was Rp 183,611,420/period.

\section{Value Added Analysis}

Value added analysis was a method of estimating the extent to which raw materials that receive treatment or changes so that they add value. The added value of $\mathrm{BC}$ products derived from raw materials such as ground lumps, rejected lumps, or tatal, after processing become a product namely BC. In other words, added value was the difference between the output value and the related input and processing costs. The supporting costs in this analysis were the cost of water and the cost of fuel (diesel). Based on the calculation results, it was known that $32.34 \%$ of $\mathrm{BC}$ product value was added value of rubber processing material in the form of ground lumps, rejected lumps, and tatal. The analysis of the value added of BC's product processing industry can be seen in Table 6 .

Table 6. Calculation of added value of brown crepe (BC) products

\begin{tabular}{lll}
\hline No & Variable & Total \\
\hline I. & Output, Input, and Price & 29.615 \\
1. & Output $(\mathrm{kg})$ & 43.000 \\
2. & Input $(\mathrm{kg})$ & 84 \\
3. & Labor $(\mathrm{HOK})$ & 0,689 \\
4. & Conversion factor & 0,002 \\
5. & Labor coefficient & 6.200 \\
6. & Output price $(\mathrm{Rp} / \mathrm{kg})$ & 158.652 \\
7. & Labor wage $(\mathrm{Rp} / \mathrm{HOK})$ & \\
II. & Revenue and Value Added & 3.060 \\
8. & Raw material price $(\mathrm{Rp} / \mathrm{kg})$ & 1.134 \\
9. & Contribution of other inputs $(\mathrm{Rp} / \mathrm{kg})$ & 6.200 \\
10. & Output value $(\mathrm{Rp} / \mathrm{kg})$ & 2.005 \\
11. & a. Added value $(\mathrm{Rp} / \mathrm{kg})$ & 32,34 \\
12. & b. Added value ratio $(\%)$ & 450 \\
& a. Labor income $(\mathrm{Rp} / \mathrm{kg})$ & 22.44 \\
\hline
\end{tabular}

Source: Primary data processing, 2018.

\section{Profitability}

Profitability (return on equity) is the ability of a company to obtain profit (profit), which is a measure used to assess the extent to which a company is able to generate income (income) available to company owners over the capital they invest in the company. In other words, profitability (economy) or return on equity (ROE) is a measurement of the company's overall ability to generate profits with all assets available in the company. Furthermore, in this study profitability was measured by profits (profits) generated by the company.

Based on the calculation, the profit generated from the processing of the $\mathrm{BC}$ product was $\mathrm{Rp} 230 / \mathrm{kg}$ or $\mathrm{Rp}$ $6,811,450 /$ period, which was the ratio between the profit and the total cost described in percentages. Based on the calculation of the profitability of BC's product processing industry was $3.84 \%$, meaning that each use of production input was Rp 1, it will generate a profit of Rp 3.84. So the $\mathrm{BC}$ product processing industry was said to be a business that provides benefits to entrepreneurs because the value of profitability was greater than zero. Furthermore, when compared with the interest rate of the KreditUsaha Rakyat, the $\mathrm{BC}$ product processing industry shows a profit rate of six times exceeding the KUR interest rate (2018) of 7\%/year.

The research indicates that industrial gross margin produces a value of $\mathrm{Rp} 622 / \mathrm{kg}$. This situation shows that the gross margin of processing BC products was very thin, which was only $10.03 \%$ of the price received by entrepreneur. Based on the benchmark level margin, BC's product processing business was at a very risky level because gross margins were below $<15 \%$, whereas a business should have a gross margin of more than $25 \%$ (Lieshout, 2015). Debertin (2010) indicate that input supply start when the price of the product above (average) variable cost. On the dry season, rubber production was greatly reduced, hence raw material of $\mathrm{BC}$ was very limited, especially raw materials originating from rejected lumps because many crumb rubber manufacturers still receive lumps of farmers with slightly lower quality. As a result, input price was increased and so output price. This situation this situation creates a new gross margin which was $\mathrm{Rp}$ $1,958(23.74 \%)$. This figure gives higher than the original one since the increase of output price was higher than the increase of raw materials. 


\section{"Analysis of Brown Crepe Industry Performance in Banjar Regency South Kalimantan Province Indonesia"}

In this research, less gross margin in the $\mathrm{BC}$ product processing industry was caused by the many costs borne by entrepreneur. Firstly, service fee for capital investment which was Rp 200/kg. As long as the capital was not returned, the amount will continue to be borne by the entrepreneur. This amount was almost the same as profit obtained by the BC producer. In addition, the producer also hands over an interest of $9 \%$ as he borrows a loan to bank (BRI) which was amounted Rp 200,000,000. The interest

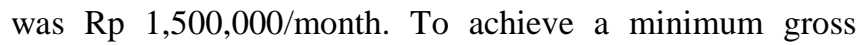
margin of $25 \%$, one effort was to provide sufficient capital through grants or interest-free loans (remuneration) to the entrepreneur. As a result, it will decrease production cost.
Another alternative was to lower input (raw material) price by cutting margin marketing of the input. Since BC producer was limited and its products (oligopolistic market), therefore the price of $\mathrm{BC}$ product was very likely to be higher. If the price was higher, the revenue would increase, hence the gross margin and the probability.

Business profitability can be improved by maximized production capacity since fixed costs do not depend on the output produced. Thus, it booster business profitability. However, it does not affect gross margin. Using Cigar-Box method, several scenarios can be raised. The following table indicates scenarios that have gross margin greater than $25 \%$.

Table 7. Scenarios of BC production that shows gross margin of $25 \%$ or more

\begin{tabular}{|c|c|c|c|c|c|c|c|c|}
\hline \multirow{2}{*}{ No } & \multirow{2}{*}{ Scenario } & \multirow{2}{*}{$\begin{array}{c}\text { Fee } \\
(\mathrm{Rp} / \mathrm{kg})\end{array}$} & \multicolumn{2}{|c|}{ Price $(\mathrm{Rp} / \mathrm{kg})$} & \multicolumn{2}{|c|}{ Gross margin } & \multicolumn{2}{|c|}{ Profit/period } \\
\hline & & & Input & Output & $\mathrm{Rp} / \mathrm{kg}$ & $\%$ & $\mathrm{Rp} / \mathrm{kg}$ & $\%$ \\
\hline 1 & Price of raw material decrease by $21 \%$ & 200 & 2.418 & 6.200 & 1.555 & 25,08 & 1.163 & 23,09 \\
\hline 2 & $\begin{array}{l}\text { Price of raw material decrease by } 16,5 \% \text {, no } \\
\text { investor's fee }\end{array}$ & 0 & 2.418 & 6.200 & 1.555 & 25,08 & 1.163 & 23,09 \\
\hline 3 & Price of output increase by $20 \%$ & 200 & 3.060 & 7.440 & 1.862 & 25.03 & 1.470 & 24,62 \\
\hline 4 & $\begin{array}{l}\text { Price of } \mathrm{BC} \text { product increase by } 16 \% \text {, no } \\
\text { investor's fee without fee }\end{array}$ & 0 & 3.060 & 7.192 & 1.814 & 25.22 & 1.422 & 24.64 \\
\hline 5 & $\begin{array}{l}\text { Price of input lowered by } 10,5 \% \text {, and price of } \\
\text { output has raised by } 10,5 \%\end{array}$ & 200 & 2.739 & 6.851 & 1.740 & 25.39 & 1.347 & 24,48 \\
\hline 6 & $\begin{array}{l}\text { Price of input lowered by } 8 \% \text {, and price of output } \\
\text { has raised by } 8 \% \text {, no investor's fee }\end{array}$ & 0 & 2.816 & 6.696 & 1.673 & 24.99 & 1.281 & 23.66 \\
\hline
\end{tabular}

Source: Primary Data, 2018.

\section{Break-even Point Analysis}

Furthermore, the analysis also showed that the breakeven point occurs when the entrepreneur produces as much as $18,676 \mathrm{~kg} /$ period, at which time the company did not make profit. According to Lieshout, (2015b), break-even point analysis was used to determine how much the price of the product was in accordance with the company's goal of obtaining the set profit target. Break-even point analysis was generally used if product prices are still unknown. This condition often occurs in products that have certain characteristics such as handicrafts. In agriculture, breakeven analysis is used in contract farming systems, where variable costs and fixed costs are known, as well as the number of products to be traded. In these circumstances, the product price can be determined based on the company's profit target.

Break-even point analysis can also be developed to find out how many raw materials must be prepared to meet the production process. In the calculation, break-even point of output was $18,676 \mathrm{~kg} /$ period, the required raw material was $23,245 \mathrm{~kg}$ of ground lump (assuming $80 \%$ will be exsiccated). Likewise, the minimum price that must be paid by the consumer was Rp 5,970/kg. Furthermore, the break- even points for variable costs (VC) that was Rp 5,808/kg, while the break-even point for fixed costs (FC) was Rp $18,417,170$. Generally, the break-even value of fixed costs is rarely found, but is more often found in products in the service sector. From the calculation, the magnitude of the break-even point of fixed costs was nothing but the amount of contribution, namely gross margin multiplied by the number of products sold. Furthermore, the analysis also showed that the break-even point occurs when the entrepreneur produces as much as $23,500 \mathrm{~kg} /$ period(ceteris paribus).

\section{CONCLUSION AND SUGGESTION CONCLUSION}

1. The added value produced by transforming raw materials (land lumps, rejected materials, and tatal) into $\mathrm{BC}$ products provides added value of $\mathrm{Rp}$ $2,005 / \mathrm{kg}$ with a value-added ratio of $32.34 \%$.

2. The total costs incurred by $\mathrm{BC}$ product processing business was Rp 176,808,764/period consisting of

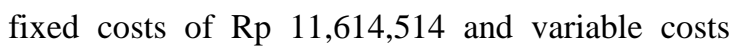
incurred in the amount of Rp 165,194,250/period. On the other hand, total BC products produced was 


\section{"Analysis of Brown Crepe Industry Performance in Banjar Regency South Kalimantan Province Indonesia"}

$29,615 \mathrm{~kg}$ in a month. With the selling price was $\mathrm{Rp} 6,200 / \mathrm{kg}$, so that revenue obtained was $\mathrm{Rp}$ 183,611,420. The profit generated was $\mathrm{Rp}$ $6,802,656$ or Rp $230 \mathrm{~kg}$. Gross margin generated from the business was only $10.03 \%$, which was very little and was considered that the business was in high risk.

3. When the availability of raw materials was limited (dry season), BC production decrease, hence it leads BC selling price increase. This gives an increase of gross margin becomes $13.26 \%$ and profitability was $\mathrm{Rp} 430 / \mathrm{kg}$ which was still far from normal risk of the business.

4. Scenario of decreasing input price by reducing marketing costs of $10,5 \%$ and increasing market value of $\mathrm{BC}$ product by $10.5 \%$ will give gross margin on the same percentage applies $25,39 \%$. In case of there was no incentive for the investor, reducing input price only $8 \%$, and at the same percentage applies to increase selling price.

\section{SUGGESTIONS}

1. Since the value added of BC product was quite significant, therefore the business should be supported by the government and other stakeholders.

2. Considering the gross margin generated by the BC business was still very low, it was expected that the role of the government in providing assistance in the form of capital with no interest or other efforts so that costs can be reduced which will reach normal gross margins.

3. Scenario of maximized production capacity also need to be considered in order to increase profits and create job in rural area well as the utilization of low quality rubber materials namely soil lumps, rejects, and tatal.

4. Further analysis needs to be done to see the prospect of developing $\mathrm{BC}$ industry in a wider scope.

\section{REFERENCES}

1. Achchuthan, S., \&Kajananthan, R. (2012). A Study on Value Chain Analysis in Dairy Sector Kilinochchi District, Sri Lanka. Global Journal of
Management and Business Research, Volume 12 Issue 21 Version 1.0. pp $1-14$

2. Alnawaiseh, M. A. L. I., Al-Rawashdi, F. M., \& Alnawaiseh, M. (2014). The Extent of Applying Value Chain Analysis to Achieve and Sustain Competitive Advantage in Jordanian Manufacturing Companies. International Business Research; Vol 7, No 8.

3. Debertin, D. L. (2012). Agricultural Production Economics. Second Edition. Amazon Createspace.

4. Dudin, M., Kucuri, G., Fedorova, I., Dzusova, S., Namitulina, A.(2015). The Innovative Business Model Canvas in the System of Effective Budgeting. Asian Social Science, Vol. 11, No. 7, pp 290 296.

5. Fielt, E. (2013). Conceptualising Business Models: Definitions, Frameworks and Classifications. Journal of Business Models, Vol. 1, No. 1 pp. 85 105.

6. Hayami, K., \&Siregar, M. (1987). Agricultural Marketing and Processing in Upland Java. A Perspective From a Sunda Village, CGPRT. Bogor.

7. Lieshout, O.(2015a). Manual for the Use of CB1. Cost Price Calculations Made Easy

8. _ (2015b). Farmers Financing Firms. Economic Farm Logbook. Organized Farmers as Partners in Agribusiness (OPPO) Training, Wageningen University Research, The Netherland.

9. Mulyadi. (2011). Akuntansi Manajemen. Salemba Empat, Jakarta

10. Porter, M. E. (1985). Competitive AdvantageCreating and Sustaining Superior Performance, New York: Free Press.

11. Qastharin, A. R. (2016). Business Model Canvas for Social Enterprise. Journal of Business and Economics, Volume 7, No. 4, pp. 627-637. Academic Star Publishing Company, USA.

12. Wikipedia. (2017). Cigar Box Method. https://en.wikipedia.org/ wiki/Cigar_Box_method. 19 April 2017.

13. Solihah, E., Hubeis, A. V. S, \& Maulana, A. (2014). Analisis Model Bisnis Pada KNM Fish Farm Dengan Pendekatan Business Model Canvas. Jurnal Sosial Ekonomi Kelautan dan Perikanan, Vol. 9 No. 2, hal. 185-194. 